\title{
A Flawed Prophecy? Zakhor, the Memory Boom, and the Holocaust
}

Gavriel D. Rosenfeld

grosenfeld@fairfield.edu

Follow this and additional works at: https://digitalcommons.fairfield.edu/history-facultypubs

Copyright 2007 University of Pennsylvania Press, The Jewish Quarterly Review.

All rights reserved. Except for brief quotations used for purposes of scholarly citation, none of this work may be reproduced in any form by any means without written permission from the publisher. For information address the University of Pennsylvania Press, 3905 Spruce Street, Philadelphia, Pennsylvania 19104-4112

\section{Peer Reviewed}

\section{Repository Citation}

Rosenfeld, Gavriel D., "A Flawed Prophecy? Zakhor, the Memory Boom, and the Holocaust" (2007). History Faculty Publications. 39.

https://digitalcommons.fairfield.edu/history-facultypubs/39

\section{Published Citation}

Rosenfeld, Gavriel D. "A Flawed Prophecy? Zakhor, the Memory Boom, and the Holocaust," The Jewish Quarterly Review, Vol. 97, No. 4 (Fall, 2007), pp. 508-520.

This item has been accepted for inclusion in DigitalCommons@Fairfield by an authorized administrator of DigitalCommons@Fairfield. It is brought to you by DigitalCommons@Fairfield with permission from the rightsholder(s) and is protected by copyright and/or related rights. You are free to use this item in any way that is permitted by the copyright and related rights legislation that applies to your use. For other uses, you need to obtain permission from the rights-holder(s) directly, unless additional rights are indicated by a Creative Commons license in the record and/or on the work itself. For more information, please contact digitalcommons@fairfield.edu. 


\title{
A Flawed Prophecy? Zakhor, the Memory Boom, and the Holocaust
}

\author{
GAVRIEL D. ROSENFELD
}

\begin{abstract}
When IT FIRST APPEARED in 1982, Yosef Hayim Yerushalmi's Zakbor seemed an anxious book - anxious about the state of Jewish collective memory, about the alleged role of professional historians in weakening it, and about the future of Jewish historical consciousness overall. Twentyfive years later, it is clear that many of the anxieties that underpinned Zakbor were unfounded. Much of what Yerushalmi explicitly viewed with foreboding - most notably, the conquest of memory by history - has not come to pass. Ironically enough, the reverse has proven to be the case, as the discipline of history has faced an enormous challenge by the emergence of what has been called the memory "boom." Relatedly, and perhaps more significantly, Yerushalmi failed to foresee one of the controversial phenomena that has stood at the center of the memory boom: the dramatic growth of Holocaust memory. Especially in light of the concerns that these two trends have sparked within some Jewish circles in recent years, the anxieties that informed Zakbor seem today far less pressing than they did when the book first appeared. For these reasons, while
\end{abstract}

1. The concept of a memory boom and a related memory "industry" has been discussed by scholars since the early 1990s. See, for example, Charles Maier, "A Surfeit of Memory? Reflections on History, Melancholy, and Denial," History co Memory 5.2 (fall/winter 1993): 143; Andreas Huyssen, Twilight Memories: Marking Time in a Culture of Amnesia (New York, 1995), 8; Kerwin Lee Klein, "On the Emergence of Memory in Historical Discourse," Representations 69 (winter 2000): 127-50. Jay Winter, "The Generation of Memory: Reflections on the "Memory Boom' in Contemporary Historical Studies," Bulletin of the German Historical Institute 27.3 (2000): 69-92 (a revised version was published as "The Memory Boom in Contemporary Historical Studies," Raritan 31.1 [summer 2001]: 52-66); idem, Remembering War: The Great War between Memory and Hwtory in the Twentietb Century (New Haven, Conn., 2006).

The Jew'is Quarterly Review' (Fall 2007)

Copyright (C) 2007 Center for Advanced Judaic Studies. All rights reserved. 
Zakbor has retained its reputation as a perceptive and erudite work of history, it may be viewed as a flawed work of prophecy.

As is well known, Zakbor offered a novel thesis about the overarching trajectory of Jewish historical consciousness from the biblical to the modern age. According to Yerushalmi, the Jewish view of history was originally a unified one that combined a mundane view of the Jewish people as active agents in history along with a metahistorical, mythic view of the Jews as a people whose historical experience was directly shaped by divine agency. During Antiquity, in other words, Jewish history and memory were fused. The frequent biblical injunction to "remember," and the ways in which "ritual and recital" were meant to reinforce memory, Yerushalmi argued, were all devoted to preserving an awareness of "God's acts of intervention in history," whether they be his liberation of the Hebrews from Egyptian bondage or his granting of the Mosaic Law. ${ }^{2}$

With the destruction of the Second Temple, the loss of national sovereignty, and the onset of exile, however, the two strands of Jewish historical consciousness became separated and "the Jews virtually stopped writing history" (p. 16). Now, when they experienced mundane historical events, the Jews interpreted (but rarely recorded) them in strictly metahistorical terms. During the rabbinic period, Jews displayed little interest in exploring recent history - for example, that of Rome or the Second Temple period - and instead preferred to perceive events as reflective of "the continuing intervention of God in history" (p. 25). ${ }^{3}$ In medieval Europe, similarly, Jews tended to assimilate new historical events into "old and established conceptual frameworks" and "familiar archetypes" (p. 36). As Yerushalmi memorably described it, the Jews developed a typological perspective in which

the latest oppressor is Haman, and the court-Jew who tries to avoid disaster is Mordecai. Christendom is "Edom" or "Esau," and Islam is "Ishmael." Geographical names are blithely lifted from the Bible and affixed to places the Bible never knew, and so Spain is "Sefarad," France is "Zarefat, [and] Germany is "Ashkenaz." (p. 36)

Even radically new events, such as the Crusades, were ultimately seen through older archetypes, such as the binding of Isaac, and preserved

2. Yosef Hayim Yerushalmi, Zakbor: Jewish History and Jewis Memory (New York, 1989), 11. In this essay, I have used this second edition of the book.

3. The metahistorical purpose of Jewish history was clear to all: namely, hastening "the establishment of the kingdom of God on earth" by responding appropriately to destruction and proving worthy of redemption. Zakbor, 21-24. 
in memory not through the means of conventional historiography but religiously rooted vehicles like penitential prayers known as selibot, memorial books written for Yizkor services, and Second Purims, which celebrated the deliverance of Jewish communities from harm (pp. 45-46).

The only exception to this typological perspective, Yerushalmi pointed out, was a faint flame of Jewish historiographical activity that flickered in the sixteenth-century in the wake of the Spanish expulsions, as Jews tried to make sense of what seemed to many like an unprecedented catastrophe. But despite the publication of such pioneering works as Azariah de Rossi's history of the Jews, Me'or 'enayim, in 1575, which used profane, non-Jewish sources to rethink and ultimately cast doubt upon received rabbinic views of Jewish history - such as the legend that a flea killed the Roman emperor Titus - most Jews during the period ignored history. Instead, they devoted their creative efforts to mythic enterprises, most notably, the study of the Kabbalah, which explained the sad history of Jewish suffering and offered the promise of redemption and hope (pp. 69-75). In this sense, Jews again favored myth over history.

Only with the dawn of modernity, according to Yerushalmi, did the Jews regain an appreciation for history's utility. With the founding of the Society for the Culture and the Scientific Study of the Jews in early nineteenth-century Germany, Jews increasingly embraced history as part of the larger project of religious and cultural self-assessment to prove themselves worthy of emancipation. At the same time, however, their embrace of history reflected the corrosive impact of assimilation upon Jewish memory - understood in the broad sense, according to Yerushalmi, as "Jewish tradition" (p. 99). Having recently emerged from their ghetto existence in the wake of the French Revolution, those Jews who felt the need "to examine Judaism historically did so," Yerushalmi noted, "because they were no longer sure of what Judaism was." Their embrace of history essentially reflected "the ever-growing decay of Jewish group memory" and the effort to make history a surrogate "faith of fallen Jews" (p. 86). Ever since, Jewish historiography had contributed to the weakening of Jewish memory. ${ }^{4}$ Not only had its requirements of scientific objectivity eroded the metahistorical, mythic, and providential features that long defined Jewish historical consciousness but history's larger

4. To be sure, it was not the sole factor responsible for it. As Yerushalmi noted: the "decline of Jewish collective memory in modern times is only a symptom of the unraveling of that common network of belief and praxis through whose mechanisms . . the past was once made present." Ibid., 94. 
quest to reconstruct the "total past" considerably "cut against the grain of collective memory, which . . . is drastically selective" in nature (pp. 94-95). The result, for Yerushalmi, was that "only in the modern era do we really find, for the first time, a Jewish historiography divorced from Jewish memory" (p. 93). Worse still, this separation had helped hasten the "decay of Jewish memory" overall (ibid.).

Following this bleak conclusion, Zakbor left the realm of analysis for advocacy, ceasing merely to describe the evolution of the Jewish past and instead prescribing recommendations for the future. It is true that the ideas Yerushalmi broached in this section of the book were colored by a certain degree of ambivalence; yet, they reflected his refusal to simply abide by the status quo. This ambivalence was most visible in Yerushalmi's belief that historians had some kind of role to play-even if only a limited one-in arresting the decay of Jewish memory. Even if they could not function as " "physician[s] of memory," who could "restore the past to us all," Jewish historians could address some of the shortcomings of their craft that prevented it from extending its popular reach (p. 93). In this regard, Yerushalmi suggested that historians would be well advised to avoid "antiquarianism" in their research and reacquaint themselves with the narrative techniques of literature so as to lend their works a greater degree of "evocation" (p. 100). More ambitiously, Yerushalmi considered the possibility that historians might be able somehow to satisfy the desire of many Jews for "a new metahistorical myth" (p. 98) that might be able to tie Jews together once again through the embrace of a unified historical perspective. In the end, however, while he confessed that he was "far from immune to the seductions of myth," Yerushalmi declared that he did not know how it would be possible for the historian to fulfill his professional obligation of "build[ing] a bridge to his people" (p. 100). The decay of Jewish memory, he feared, would proceed apace. And historians would be partly responsible (p. 99).

As fate would have it, however, Yerushalmi's fears for the future of memory were overstated. It is ironic that while Zakhor was ahead of its time in establishing memory as a topic of scholarly investigation, it did not fully anticipate its ultimate significance as a larger cultural phenomenon. On the one hand, it is to Yerushalmi's enduring credit that Zakhor was among the first scholarly works to place memory at the center of the historical profession's analytical gaze, appearing around the same time as other pioneering works like Pierre Nora's monumental study Les Lieux $\partial e$ Mémoire (1984), Eric Hobsbawm and Terence Ranger's The Invention of Tradition (1983), and David Lowenthal's The Past Is a Foreign Country 
(1985). ${ }^{5}$ It further speaks well for Zakbor that these studies not only affirmed the validity of Yerushalmi's analytical agenda but echoed his fears as well. All of them focused intently on the manifold connections between memory and identity (whether national, regional, or religious) and further expressed the melancholic sense that organic memory had been replaced by manufactured or "invented" history, whether in the form of new traditions, monuments, or - in the case of Zakbor-modern historiography.

On the other hand, in identifying history as partly culpable for the erosion of memory, Yerushalmi failed to recognize the looming paradigm shift that was developing with respect to memory within Western cultural and intellectual life. In the years immediately following the original publication of Zakbor, the status of memory was in the process of being dramatically enhanced. By 1989, when the second edition of the book appeared, some of the key events that would help make memory the growing focus of international attention and lead to talk of a "memory boom" had already taken place or were about to erupt. In Germany and Austria, the specter of the Nazi past was being publicly revisited in dramatic fashion in the Bitburg controversy of 1985, the Historian's Debate of 1986-87, and the Waldheim Affair of $1986 .{ }^{6}$ One year later, in 1989, the fall of communist regimes in Eastern Europe and the ensuing end of the cold war helped to unleash long-buried memories of various traumatic pasts - whether from periods of fascist or communist oppression - across the European continent during the 1990s. ${ }^{7}$ Other factors that helped drive the memory boom were also at work at the same time, such as the rise of multiculturalism - which gave new attention and heightened status to the ignored countermemories of minority groups throughout the West - and postmodernism, which, by undermining history's claims to objective truth, granted heightened status to history's alleged "other," memory. ${ }^{8}$

5. Nora's study was published in English as Realmw of Memory: The Construction of the French Pavt, the first volume of which was published by Columbia University Press in 1996; Eric Hobsbawm and Terence Ranger, eds., The Invention of Tradition (New York, 1983); David Lowenthal, The Past Is a Foreign Country (Cambridge, 1985).

6. See Charles Maier, The Unmasterable Pavt: History, Holocawt and German National Identity (Cambridge, Mass., 1988).

7. See Tony Judt's important article "The Past Is Another Country: Myth and Memory in Postwar Europe," Daedaluw 121.4 (fall 1992): 83-118.

8. Maier, "A Surfeit of Memory? Reflections on History, Melancholy, and Denial," 144-47; Klein, "On the Emergence of Memory in Historical Discourse," 143; Jan-Werner Müller, "Introduction: The Power of Memory, the Memory of 
Yet, even in the second edition of Zakbor, Yerushalmi did not pick up on the larger forces that were slowly working to enhance memory's status. This oversight was particularly visible in the second edition's new epilogue, entitled "Reflections on Forgetting," in which he persisted in seeing memory as being threatened by history. Having originally written the epilogue as a conference paper at the request of the historian Jacques Le Goff, who had invited Yerushalmi to present his thoughts at a Paris conference entitled "Hypertrophy of Memory: Forgetting of History," Yerushalmi openly objected to the conference's underlying premise, retorting: "This [conference title] I must reject. If at all, 'Atrophy of Memory: Hypertrophy of History' " (p. 105). At a time, in short, when scholars were beginning to sense the changing relationship between history and memory, Yerushalmi remained wedded to his preexisting conceptions.

And yet Zakbor did not merely fail to foresee the heightened interest in memory, it also neglected to address one of the driving factors behind it: the increasing emergence of Holocaust memory. Precisely at the time that Yerushalmi was writing the lectures that became Zakhor in the early 1980 s, the Holocaust was in the process of assuming an unprecedented degree of prominence in Jewish cultural and intellectual life. ${ }^{9}$ The factors behind this trend are as well known as they are varied. Jewish anxieties about the possibility of a second, Arab-sponsored Holocaust at the time of the Six Day War of 1967 and the Yom Kippur War of 1973 contributed to a renewed awareness of the Nazi genocide in contemporary Jewish life. ${ }^{10}$ Not long thereafter, attempts by Eastern European communist regimes to "de-Judaize" the Holocaust, American Holocaust deniers to negate it, German conservatives to relativize it, and liberal and conservative American pressure groups to universalize its significance prompted Jewish scholars and journalists to defend and reassert its uniquely Jewish

Power, and the Power over Memory," Memory and Power in Postwar Europe: Studies in the Presence of the Past, ed. idem (Cambridge, 2002), 16; Winter, Remembering War, 34-36; Barry Schwartz, "Introduction: The Expanding Past," Qualitative Sociology 19.3 (1996): 277-78.

9. This awareness was first noted in Jewish publications like Commentary and Midstream in the early 1980s. Edward Alexander, "Stealing the Holocaust," Midstream 26.9 (November 1980): 46-50; Robert Alter, "Deformations of the Holocaust," Commentary 71.2 (February 1981): 48-54; see also Michael Berenbaum, "The Uniqueness and Universality of the Holocaust," American Journal of Theology and Pbilosophy 2 (September 1981), reprinted in John K. Roth and Michael Berenbaum, eds., Holocaust: Religious and Pbilosophical Implications (New York, 1989), 82-97.

10. This argument features significantly in Peter Novick's The Holocaut in American Life (New York, 1999). 
dimensions. ${ }^{11}$ This campaign found political support with President Jimmy Carter's chartering of the United States Holocaust Memorial Museum in 1979 and with the sponsoring of local Holocaust memorials and museums in cities all across the United States throughout the $1980 \mathrm{s.}^{12}$

By the early 1990s, these efforts had reached the necessary tipping point to produce a broader awareness of the Holocaust not just within Jewish circles but within Western popular consciousness overall. In the United States, the dedication of the United States Holocaust Memorial Museum in 1993 and the release of Steven Spielberg's Oscar-winning film Schindler's List the same year stoked national interest in the Holocaust, while in Europe, the many commemorative ceremonies surrounding the fiftieth anniversary of the end of World War II, the holding of high-profile war crimes trials of World War II perpetrators like Paul Touvier and Maurice Papon, the publication of bestselling books on the Nazi period by Daniel Goldhagen and Victor Klemperer, and the creation of national memorials and museums to the Holocaust, such as Germany's national Memorial to the Murdered Jews of Europe in Berlin, did so as well. By the turn of the millennium, these milestones, plus the invocation of the Holocaust to justify Western intervention against Serb forces in Kosovo in 1999, emboldened certain scholars to affirm the "globalization" of Holocaust memory. ${ }^{13}$ And with other scholars citing the pivotal role that awareness of the Nazi genocide had played in inspiring different persecuted groups to seek redress for historic injustices, the importance of Holocaust consciousness in helping to stimulate the worldwide memory boom was confirmed. ${ }^{14}$

Especially in light of this fact, it is striking how little Yerushalmi mentioned the Holocaust in Zakhor. Yerushalmi made only one significant reference to the Nazi genocide in his book, doing so near its conclusion in a section devoted to what he described as the Jewish people's enduring

11. See Gavriel D. Rosenfeld, "The Politics of Uniqueness: Reflections on the Recent Polemical Turn in Holocaust and Genocide Scholarship," Holocaut and Genocide Studies 13.1 (spring 1999): 28-61.

12. Edward Linenthal, Preserving Memory: The Struggle to Create America's Holocaust Museum (New York, 1995); James E. Young, The Texture of Memory: Holocaust Memorials and Meaning (New Haven, Conn., 1993).

13. Daniel Levy and Natan Sznaider, The Holocaut and Memory in the Global Age (Philadelphia, 2006).

14. John Torpey, “'Making Whole What Has Been Smashed': Reflections on Reparations," Journal of Modern History 73.2 (June 2001): 352. See also, Torpey, "Introduction," Politict and the Past: On Repairing Historical Injustices, ed. idem (Lanham, Md., 2003); Elazar Barkan, The Guilt of Nations: Restitution and Negotiating Historical Injustices (Baltimore, Md., 2000). 
yearning for myth. As Yerushalmi wrote, "it is hard to escape the feeling that the Jewish people after the Holocaust stands today at a juncture not without analogy to that of the generations following the cataclysm of the Spanish expulsion [which] . . . ultimately chose myth over history" (p. 99). In making this claim, Yerushalmi appeared to imply that most Jews had somehow shied away from confronting the full magnitude of the Holocaust's implications for Jewish history after 1945. As he went on to argue in the sentence that followed, most Jews during the postwar period had remained averse to insights provided by modern Jewish historiography. ${ }^{15}$ "Today," he noted, "Jewry lives a bifurcated life. As a result of emancipation in the diaspora and national sovereignty in Israel, Jews have fully re-entered the mainstream of history, and yet their perception of how they got there . . is . . . often more mythical than real" (p. 99).

Beyond these passing remarks, Yerushalmi devoted no further attention to the Holocaust's legacy in Zakbor. Yet, however briefly formulated, his comparison of Jewish behavior after the Spanish expulsion to that after the Holocaust-especially the idea that both flirted with history but ended up settling for myth-was highly suggestive. Indeed, although Yerushalmi himself chose not to expand upon it, his hypothesis can be seen as containing the seeds of deeper, if undeveloped, insights. Drawing on Zakbor's own core thesis, one could plausibly argue that, since 1945, many Jews have responded to the Holocaust by fashioning a secularized version of the religiously rooted, archetypal view of history identified by Yerushalmi as so widely embraced by their coreligionists in the premodern era. Just as medieval Jews interpreted the events that befell them in typological form through the prism of preexisting historical precedents, Jews in the postwar world have repeatedly perceived the unfolding of contemporary history through the traumatic paradigm of the Holocaust.

Examples of this trend are legion and can hardly be enumerated in their entirety. But several should suffice. Perhaps the most familiar is the fact that Jews in Israel and the United States have regularly described their Arab enemies as latter-day incarnations of the Nazis. Thus, Egypt's President Gamel Abdel Nasser, PLO chief Yasir Arafat, Iraqi President Saddam Hussein, and Iranian President Mahmoud Ahmedinejad have all been branded as the second coming of Adolf Hitler and have been per-

15. Yerushalmi argued more generally that a widespread "indifference ... to modern Jewish historical scholarship" existed within "certain Jewish circles," and that modern "Jewish historiography had "impinged . . little upon modern Jewish thinking and perception generally" Zakhor, 96. 
ceived as plotting genocidal policies against the Jewish people. ${ }^{16}$ Such comparisons have been made by Israeli politicians, American Jewish activists, and representatives of the media in both Israel and the United States for the better part of the last half-century. ${ }^{17}$ Further still, Jews since 1945 have not only perceived their enemies but also their coreligionists as Nazis. In 1995, right-wing Israelis infamously portrayed Prime Minister Yitzhak Rabin - then in the midst of pursuing negotiations with the Palestinians - as a Nazi and a traitor prior to his assassination, while during the same decade, left-wing Jewish academics and intellectuals in Israel, Europe, and the United States increasingly began to describe the Israeli government's treatment of the Palestinians - and Zionism overall-as Nazi-like in character. ${ }^{18}$ Such historically inflected assertions have persisted up through the present day. In 2005, the American Zionist Organization of America compared the Israeli removal of Israeli settlers from Gaza to the Nazis' deportation of Jews during the Holocaust. ${ }^{19}$ And some Israeli observers justified the 2006 war against Hezbollah in Lebanon in the name of the six million Jewish Holocaust victims. ${ }^{20}$ Whether

16. There is no denying that these Arab leaders frequently encouraged such comparisons to the Nazis with their overheated rhetoric - epitomized by Nasser's references to "driving the Jews into the sea" and Ahmedinejad's remarks about "wiping Israel off the map" - which may or may not have mirrored actual genocidal intent. Determining the legitimacy of Jewish comparisons of Arab leaders to the Nazis exceeds the boundaries of this essay.

17. For Israeli comparisons of Arab leaders to Hitler, see Tom Segev, The Seventh Million: The Israeliw and the Holocaust (New York, 1993). And more broadly, Idith Zertal, Israel's Holocaut and the Politict of Nationhood (Cambridge, 2005). For the American case, see Novick, The Holocaut in American Life.

18. "2 Israeli Boys Held for Nazi Poster of Rabin," New York Times, November $25,1995,4$. One of the more controversial examples of leftist intellectuals' usage of Nazi imagery was Yeshayu Leibowitz's use of the epithet "Judeo-Nazis to refer to Israeli settlers. For a critique of Jewish anti-Zionism that highlights various comparisons to Nazism, see Edward Alexander and Paul Bogdanor, eds., The Jewish Divide over Israel: Accusery and Defendery (Somerset, N.J., 2006). See also the flap sparked by Alvin H. Rosenfeld's essay “'Progressive' Jewish Thought and the New Anti-Semitism" (American Jewish Committee, 2006) as well as Rosenfeld's response to his critics in "Rhetorical Violence and the Jews: Critical Distance," The New Republic Online, February 27, 2007, <http://www.tnr.com/doc $. m t^{\prime m l} ? \mathrm{i}=\mathrm{w} 070226 \& \mathrm{~s}=$ rosenfeld $022707>$.

19. The ZOA-sponsored ad ran in the Forwar $\partial$ and other Jewish publications (January 6, 2005). Part of the text read: "Now, incredibly, it is Jews who would deport their own, imprison them in concentration camps and abandon the land to those who would destroy it" the ad goes on to call such plans "an abomination."

20. The Israeli journalist Ben Caspit wrote a mock speech for Ehud Olmert, which contained the line "Today I am serving as the voice of six million bom- 
representing the political right or the left, in short, many Jews throughout the postwar period have drawn on the Nazi past to make sense of the present.

To be sure, the individuals and groups that have made such comparisons have done so partly for polemical purposes; but the fact that they have utilized the Holocaust at all as an archetypal metaphor for evil and suffering suggests that Yerushalmi may have been onto something in postulating the postwar gravitation of some Jews toward mythic views of the past and present. It is difficult, of course, to offer definitive support for this supposition in the limited scope of this essay. This difficulty is compounded, moreover, by the fact that Yerushalmi made his assertions about myth in passing and never really defined his use of the term. By neglecting to do so, he left his argument open to certain objections. To cite merely one example, because "myth" has traditionally connoted a lack of historical truth, Yerushalmi's use of the term to describe postwar Jewish historical consciousness could be interpreted as reflecting the conviction that Jews since 1945 have consistently misinterpreted contemporary historical events (for example, the threats facing them in the Middle East) by perceiving them through the traumatic paradigm of the Holocaust. The problem with such an interpretation, of course, is that it neglects to measure the validity of historically inflected postwar Jewish fears, which, though perhaps exaggerated in some cases, have in others been based to a greater degree in reality and have not been "mythic" at all. In order to avoid any misunderstandings, I prefer to avoid using the term "myth" and favor Yerushalmi's more specific, and value-neutral, identification of a "typological" historical perspective among postwar Jews - one which, profoundly shaped by the experience of the Nazi genocide, has reflexively evoked it in the effort to make sense of presentday events. And yet here, too, uncertainty remains. For Yerushalmi's implicit avowal of the enduring power of Jewish memory since the Holocaust stands in tension with his claims about the accelerating decay of Jewish memory in the modern world. After all, if Jews truly have gravitated toward myth and have been indifferent to the sober truths of Jewish historiography since 1945, how endangered could Jewish memory truly be? Resolving the apparent contradiction in Zakbor between the alleged weakening of Jewish memory and the alleged Jewish preference for myth over history represents one of the key challenges for future scholars

barded Israeli citizens who serve as the voice of six million murdered Jews who were melted down to dust and ashes by savages in Europe" <http://www.nrg.co .il/online/1/ART1/457/743.html>. 
interested in assessing the ultimate validity of Yerushalmi's suggestive remarks.

But there is still another issue to consider. However much Yerushalmi may have been prescient in sensing a post-Holocaust Jewish gravitation towards myth, and however much Zakbor clearly displayed his anxieties about the future of Jewish historical consciousness, both failed to anticipate the anxieties that the prominence of Holocaust memory eventually generated within certain Jewish circles. Already in the early 1980s, leading Jewish intellectuals had begun to express reservations about the rise of Holocaust consciousness as a surrogate source of Jewish identity. ${ }^{21}$ But by the end of that decade and into the $1990 \mathrm{~s}$, a growing chorus of mostly left-leaning scholars and journalists in Israel and the United States, such as Yehuda Elkana, Tom Segev, Amos Elon, Charles Maier, and Peter Novick (in addition to polemical extremists like Norman Finkelstein), began to allege that the memory of the Holocaust was being instrumentally used to justify Israel's maltreatment of Palestinians and to claim a primacy of suffering for the Jews that ended up minimizing the historic persecution of other peoples..$^{22}$ According to this line of reasoning, the Jewish preoccupation with the Holocaust had allegedly distorted not only their understanding of history but their sense of themselves and their place in the postwar world. As one observer put it, by continually "playing the Holocaust card," Jews had failed to recognize how it made them appear less like defenseless victims in the eyes of the world than heavyhanded bullies. ${ }^{23}$ Overall, these critics reached the opposite conclusion from Yerushalmi about the status of memory. For if he feared history overwhelming memory, they argued that a "surfeit" of mythologized Holocaust memory was threatening to overwhelm a more measured and objective sense of history. By the same token, if Yerushalmi openly con-

21. Ismar Schorsch, "The Holocaust and Jewish Survival," Midstream 27.1 (January 1981): 38-42.

22. Yehuda Elkana wrote a much commented-upon essay, "In Praise of Forgetfulness," Ha'aretz (Hebrew), March 2, 1988, 18. Tom Segev commented upon it in his book, The Seventh Million, 502-3, as did Amos Elon in his essay "The Politics of Memory," New York Review of Books, October 7, 1993, 3-5. Charles Maier questioned the rise of Holocaust consciousness in the context of the United States Holocaust Memorial Museum in Washington D.C. in his essay "A Surfeit of Memory?"; Peter Novick's book, The Holocaut in American Life, extensively surveyed the subject, and Norman Finkelstein's seriously flawed study, The Holocaut Industry, did the same.

23. Ami Eden, "Playing the Holocaust Card," New York Times, January 29, $2005,19$. 
fessed to his "terror of forgetting," they boldly claimed that "a little forgetfulness might finally be in order." ${ }^{24}$

Whatever the flaws of the arguments mobilized by the critics of Holocaust memory (and I do not have the space to enumerate them here), the main point is that Yerushalmi failed to anticipate their emergence, let alone their vehemence. Neither, as a result, did he anticipate the ongoing debate that has raged between the critics and defenders of Holocaust memory ever since. To be sure, given the limited ambitions of Zakbor, Yerushalmi cannot be held accountable for all these oversights. But with that caveat in mind, there is another telling omission that deserves at least passing mention. No matter how much Yerushalmi may have been right in sensing an inclination toward myth and an indifference to history among many Jews in the wake of the Holocaust, he may not have gone far enough in his assessment. Despite the massive wave of historical scholarship produced on the Holocaust in recent decades, there is evidence that Jewish historians themselves have largely neglected the Holocaust in their work and refused to consider its implications for their historiographical and ideological positions on the larger themes of modern Jewish history. ${ }^{25}$ This supposition seems true in the case of Zakbor, which merely alludes to, and ultimately fails to wrestle with, the Nazi genocide in any direct way. In the end, if Zabkor is any example-and if it is true that professional Jewish historians have largely kept the Holocaust at arm's length as well - then perhaps we ought not be surprised if many ordinary Jews have done the same and exhibited an inclination toward a typologically based, mythologically oriented historical perspective.

Finally, it is worth adding that it is not just the status of the Holocaust within Jewish consciousness but other topics as well that should lead us to further explore Yerushalmi's hypothesis about the postwar Jewish penchant for myth. In remarking that most Jews have had little idea about how they had arrived in the "mainstream of history" since 1945, Yerushalmi alluded to the creation of the state of Israel as a pivotal event that had implicitly remained shrouded in myth as well. This claim is argu-

24. Elon, "The Politics of Memory," 5.

25. This is the recent argument of David Engel, who has pointed out that research into the Nazi genocide has largely been advanced by scholars outside the field of Jewish history, in disciplines such as social history or cultural studies. The result, he notes, is that "the Holocaust has not exerted any notable influence [on] . . . the study of Jewisth history." David Engel, On Studying Jewist History in Light of the Holocaut (United States Holocaust Memorial Museum, Washington D.C., 2003), 8. 
ably confirmed by the controversial reception that post-Zionist historical scholarship has received within many Jewish circles. Just as Azariah de Rossi earned little but scorn from Jewish readers in seeking to dismantle rabbinic myths in the seventeenth century, post-Zionist historians' efforts to challenge what they have viewed as the mythic views of the events leading up to and following the state of Israel's founding in 1948 have been criticized by many Jews inside and outside Israel. ${ }^{26}$ While the claims of post-Zionist historians remain contested today, and while they themselves could be accused of developing a negative mythology about the state of Israel-one no less subjective than the positive mythology they have tried to challenge - historical knowledge of the state of Israel overall continues to be defined by mythologizing tendencies. ${ }^{27}$

What these trends reveal about Zakbor's ultimate legacy twenty-five years after its original publication seems clear. From the perspective of today, the book's significance lies less in its extensively argued, but illfounded, concerns about the atrophying of Jewish memory than its cursorily noted, but perceptive, supposition about a persisting Jewish inclination toward myth. Zakhor has hardly had the final word on this subject, of course. But if the book inspires scholars to investigate it in further detail, it will have left a significant legacy indeed.

26. For surveys of the post-Zionist controversies, see the special issue of $H \dot{w}$ tory o' Memory 7.1 (spring/summer 1995) entitled "Israeli Historiography Revisited." See also Laurence J. Silberstein, The Post-Zionism Debates: Knowledge and Power in Israeli Culture (New York, 1999). Various post-Zionist theses have made inroads, of course, into Jewish educational institutions and consciousness more broadly.

27. One example of this trend appeared in 2001 when Likud education minister Limor Livnat decided to cancel the publication of a post-Zionist-influenced history textbook approved for Israeli high school students by the previous Labor education minister, Yossi Sarid, in favor of a more patriotic text. See Jessica Steinberg, "Education Minister Vows to Undo 'Post-Zionist' Critique," Jewish Telegraphic Agency, May 18, 2001. 